\title{
Assessing the Application Potential of Selected Ecosystem-based, Low-regret Coastal Protection Measures
}

C. Gabriel David ${ }^{1}$, Nannina Schulz ${ }^{1}$ and Torsten Schlurmann ${ }^{l}$

\section{$1 \quad$ Abstract}

Climate change and subsequent processes triggered by climate change demand novel assessments and protection schemes in coastal environments, as frequency and intensity of extreme events as well as mean sea water levels are expected to rise. Most often, conventional coastal engineering approaches are solely built for protection purposes, but often come with negative side-effects to the coastal environment and communities. During the last decade, new concepts in coastal engineering have started emerging. Several technical measures with an ecosystem-based design have been developed and, in some places, already implemented over the last decade. These low-regret measures, for instance green belts, coir fibers and porous submerged structures, reveal their full potential as stand-alone coastal protection or when used in combination with each other. They are believed - and in some cases documented - to be a better alternative or potential complement to conventional "hard" coastal engineering protection. Concrete examples are taken from the densely populated coastal area of Jakarta Utara (North Jakarta) and the National Capital Integrated Coastal Development (NCICD), showing benefits and further opportunities, but also challenges for applied low-regret coastal protection measures and ecosystem-based disaster risk reduction. An assessment of the application potential of three "soft" protection measures is given and discussed.

${ }^{1}$ Franzius Institute for Hydraulics, Estuarine and Coastal Engineering*, Leibniz University of Hanover; Nienburger Straße 4; 30167 Hannover, Germany; david@fi.uni-hannover.de

*Now: Ludwig Franzius Institute of Hydraulic, Estuarine and Coastal Engineering

Peer-reviewed and for publication accepted manuscript in:

Ecosystem-based Disaster Risk Reduction and Adaptation in Practice

Springer International Publishing

Editors: F.G. Renaud, K. Sudmeier-Rieux, M. Estrella, U. Nehren

$\begin{array}{ll}\text { eBook ISBN } & 978-3-319-43633-3 \\ \text { DOI } & 10.1007 / 978-3-319-43633-3 \\ \text { Hardcover ISBN } & 978-3-319-43631-9 \\ \text { Softcover ISBN } & 978-3-319-82872-5 \\ \text { Series ISSN } & 1878-9897 \\ \text { Edition Number } & 1 \\ \text { Number of Pages } & \text { XXII, 598 } \\ \text { Article Pages } & 457-482\end{array}$




\section{Motivation to Develop New Low-regret Coastal Protection Systems}

Coasts and estuaries are increasingly exposed to rising sea levels, varying extreme weather and climate events. The likely impacts are due, on the one hand, to gradual processes (e.g. sea-level rise, coastal erosion, salt intrusion in estuarine systems and nearshore morphological changes) and, on the other hand, to single extreme events (e.g. storms and storm surges), together with increasing threats and human pressure.

Recently, increased attention has been paid to manage risks of extreme events through the "Special Report on Managing the Risks of Extreme Events and Disasters to Advance Climate Change Adaptation" published in 2012 by the Intergovernmental Panel on Climate Change (IPCC). The report contains a diverse portfolio of innovative options of "low-regret" adaptation measures for coastal protection. Protection measures are characterised as being "low-regret", if they yield benefits regardless of the climate scenario but are not cost-free (Wilby and Keenan 2012 pg. 1), or if they are beneficial regardless of climate change impacts. Moreover, these measures will improve the adaptability of the system to the natural variability in climate patterns (Bou-Zeid and El Fadel 2002 pg. 1). The fifth IPCC report (IPCC 2012 pg. 16), defines "low-regret" measures, as measures that provide benefits under current climate and a range of future climate change scenarios. [...] They have the potential to offer benefits now and lay the foundation for addressing projected changes. Many of these low-regrets strategies produce co-benefits, help address other development goals, such as improvements in livelihoods, human well-being, and biodiversity conservation, and help minimize the scope for maladaptation.

Such low-regret protection measures provide coastal protection by dissipating wave energy and, additionally, support local coastal ecosystems and supply ecosystem services. Coastal ecosystems such as tidal marshes, mangroves, dunes and coral or shellfish reefs generate almost $40 \%$ of all ecosystem services on our planet, with these being about twice the GDP of the world population (Costanza et al. 1997). Preserving these ecosystem services can provide additional monetary benefits in the range of $\$ 4.3$ to $\$ 20.2$ trillion/yr (Costanza et al. 2014), adding up the cost-benefit of "low-regret" adaptation measures - apart from being more sustainable and positive towards the environment itself.

Present requirements for a sustainable future are no longer met solely by conventional coastal engineering approaches. A paradigm shift from building in nature towards building with nature is necessary (Ecoshape Foundation 2013). The answer is to recreate or preserve and improve existing ecosystems with a combination of socio-economic and marine ecosystem disciplines and establish an "Ecosystem-based and Low-Regret Adaptation Management" (ELRAM).

\subsection{State of the Art}

In the past, coastal defence measures have been built mainly from the perspective of engineering and structural defence disciplines, but in order to enhance sustainability and long-term benefits of coastal protection measures, a more efficient integration of socio-economic and ecological principles and knowledge is required. Novel approaches attempt to recreate, preserve and improve existing ecosystems with a combination of socio-economic and marine ecosystem disciplines and to establish an ecosystem-based and low-regret adaptation management in coastal zones. Responses to coastal hazards therefore need to consider a broader range of solutions, which will demand transdisciplinary competences, knowledge of multiple coastal issues, and their links to ecosystems and society. In this context, typical examples of traditional, engineering-type, hard coastal protection measures are depicted on the left side and a selection of ecosystem-based, "low-regret" soft measures on the right 
side of Fig. 1. These measures are classified into categories whether they can be applied near-shore, onshore or on-site.

Traditional hard protection systems solely protect coastal areas from coastal hazards, but do not bring additional benefits, nor adapt to increasing future threats. They typically require continual and sometimes costly maintenance and need to be adapted, i.e. upgraded, to cope with sea level rise from climate change. They may also lead to or aggravate adverse effects on morphology, hydrodynamics, sediment transport, and nutrient budgets and impair the local economy (Cheong et al. 2013). "Soft", ecosystem-based protection systems also face these challenges, but concurrently attempt to improve local environmental settings, most often enhance structure and functioning of ecosystems and their services and to protect the location from typical coastal hazards.

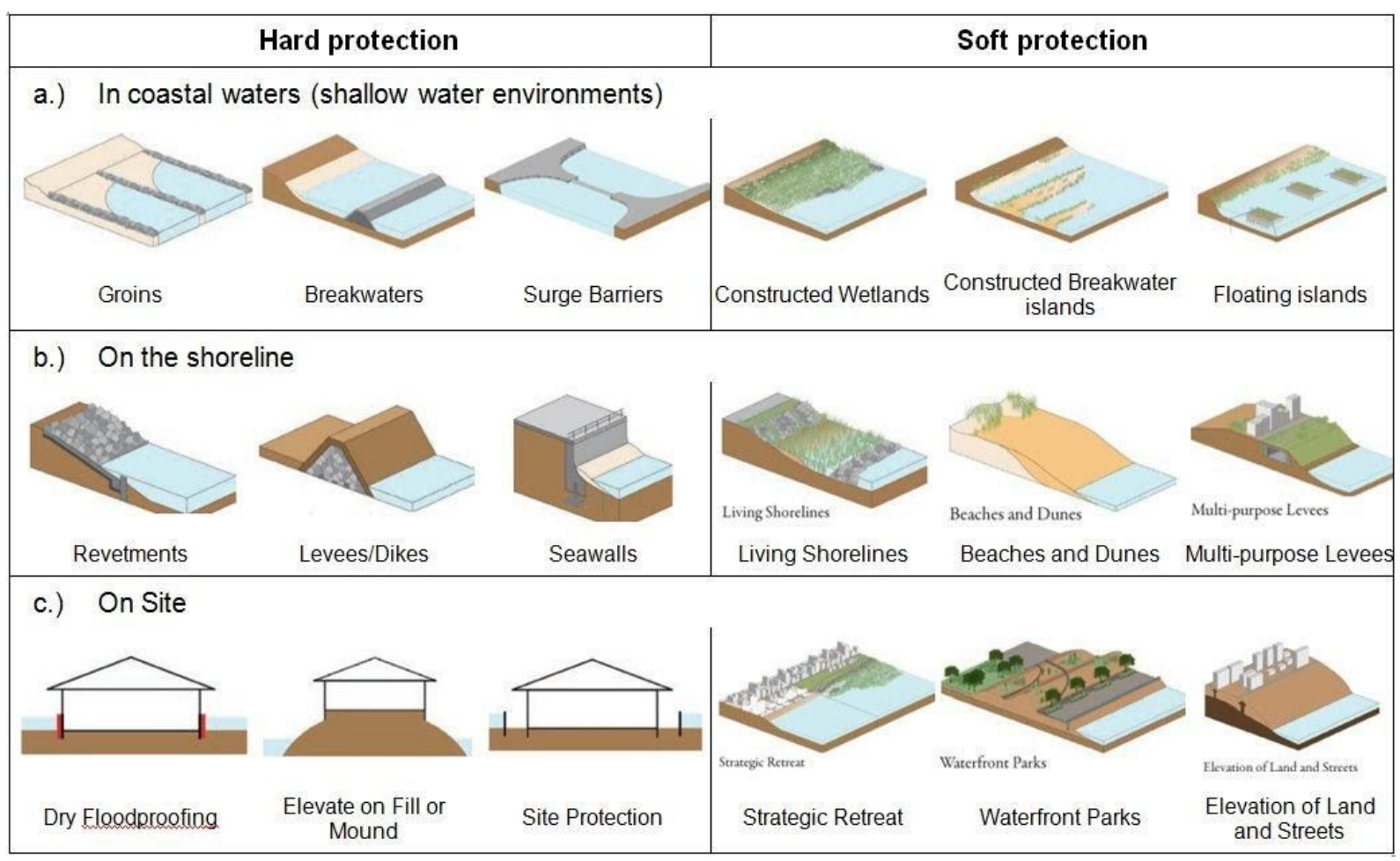

Fig. 1. Different types of hard protection (left) and soft protection measures (right) in coastal waters (a.), on the shoreline (b.) and on-site (c.) [Bloomberg and Burden 2013; reproduced with permission]

Soft protection systems are not easy to implement in practice yet. The precondition of the environment and the geographic location decide whether different ecosystem-based approaches are feasible. An additional challenge is to meet security standards and the practical application when used for infrastructural and human defence. Ecosystem-based coastal defence requires more space than conventional structures, but for highly urbanized seaside cities, space is limited. In this case, conventional hard protection or a combination of hard and soft protection measures is often the only practical approach. When space between the sea and urbanized areas on the coast increases, efficiency and effectiveness of ecosystem-based flood defence increases likewise (Temmerman et al. 2013).

As of today, the performance and efficiency of created ecosystems as flood defence systems are still to a significant degree uncertain, because only a few long-term studies exist (Temmerman et al. 2013). However, instead of pursuing one particular strategy or defence for one specific hazard, coastal adaptation measures have to be dynamic, versatile and flexible to face climate change efficiently. 
Also, a proper design considers the influence for society, ecosystems and engineering among each other (see Fig. 2, Cheong et al. 2013). Involving all shareholders in planning and decision-making creates a higher acceptance for the process and thus reduces adverse political, financial and infrastructural effects, as Cheong et al. (2013) point out in order to define a novel disciplinary approach of so-called Ecological Engineering depicted in Fig. 2.

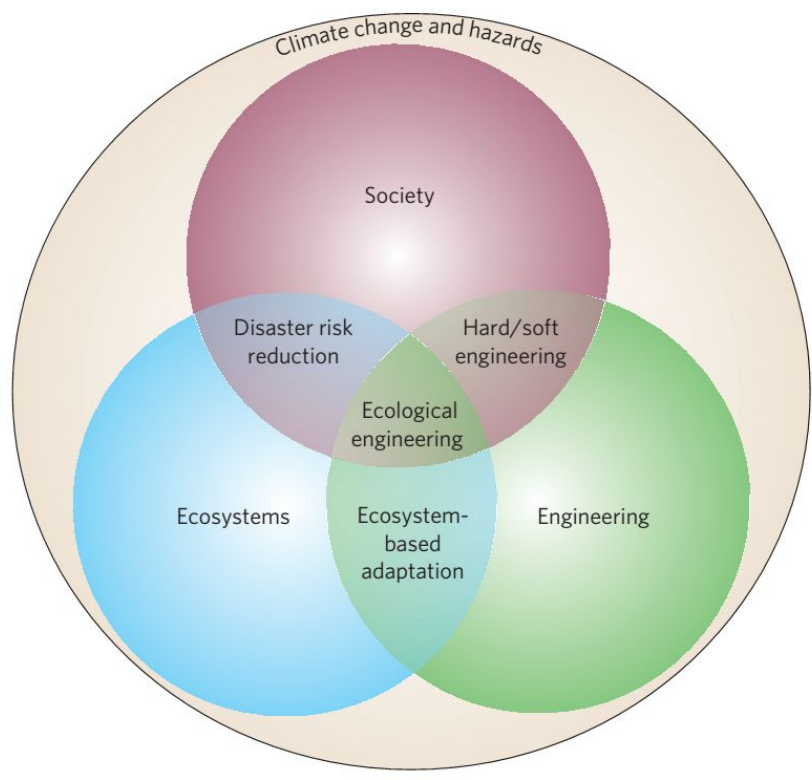

Fig. 2 Ecological Engineering - Combining strategies for coastal adaptation [Cheong et al. 2013; reproduced. with permission]

\section{$3 \quad$ Possible Measures and their Application}

Soft coastal protection methods range from strategies such as integrated coastal zone management (ICZM) and early warning systems (EWS) to engineered (infra)structures. ICZM is already part of several national laws around the world (i.e. European Union, the United States of America, Australia, Sri Lanka, etc.), and early warning systems can be found for example in reference to tsunami hazards along the coastal stretches in the whole Indian Ocean (Taubenböck et al. 2013). This chapter, however, takes a closer look at and critically assesses three types of ecological engineering approaches, with a focus on the application in Southeast Asia.

\subsection{Mangroves}

Mangrove biomes consist of different tree and shrub types, which are adapted to the conditions of the coasts and estuaries in the tidal range of areas with (sub)tropical climate (Vedharajan and Gross 2007). Mangrove trees stand on their roots, which are mostly covered with water during high tide, but are exposed to air during low tide (see Fig. 2). They are not only an important part of the ecosystem and contribute to support the livelihoods for adjacent coastal communities, but they also serve as natural coastal protection and as a typical type of green belt.

The mangroves grow on muddy, wet and intermittently submerged beds. Their dense root network traps organic compounds from upstream, thus creating a hypoxic or anoxic environment. In order to guarantee oxygen supply, many mangrove plants have developed aerial roots or pneumatophores. Mangrove roots are typically above ground and water level. They form a large root block which 
withstands wave attack and dissipates wave energy. However, the level of resistance varies depending on the root type.



Fig. 3 Natural mangrove in Senegal [by Wetlands International in Spalding et al. 2014; reproduced with permission]

\subsubsection{Protection Potential}

Several publications and reports based on field observations, physical and numerical modelling document the protection potential of mangroves in coastal areas. The trunks and branches of mangrove trees serve as a barrier for wind and swell waves (McIvor et al. 2012). They reduce current velocity, flood depth and impact due to waves, floods and high winds (Hiraishi and Harada 2003, Teo et al. 2009, GIZ 2011, Lacambra et al. 2013). Mangroves can therefore protect humans, infrastructure and agricultural land against natural hazards such as storms, typhoons, and tidal waves. The level of protection, however, depends on the specific characteristics of local mangrove forests, such as tree species, age, condition, planting density and of course height and trunk diameter, as well as submergence of plants (Mazda et al. 2006, Augustin et al. 2009, Bao 2011, Hashim et al. 2013). Hashim et al. (2013) state that wave attenuating factors are not fully understood as of today, but present approaches take several variables regarding tree dimensions and planting properties into account (Mazda et al. 1997b, Quartel et al. 2007, Mendez and Losada 2004, Augustin et al. 2009, Bao 2011, Guannel et al. 2015). McIvor et al. (2012) find a proper design approach for mangrove restoration by selecting two models: a regression model by Bao (2011) and a numerical case study by Narayan et al. (2010), based on a modified version of the numerical phase averaged model Simulating WAves Nearshore (SWAN), presented in Suzuki et al. (2012). A summary with quantitative effects of mangroves on water levels and wave heights is given in Table 1. 
Table 1 Summary of mangrove protection potential in different publications.

\begin{tabular}{|l|l|l|}
\hline Source & Effect & Condition \\
\hline Mazda et al. (1997a) & $\begin{array}{l}\text { Significant decrease for offshore wind } \\
\text { waves }\end{array}$ & $\begin{array}{l}\text { Width: 1500m belt, } \\
\text { Species: Kandelia Candel } \\
\text { mature (5-6 years) }\end{array}$ \\
\hline Quartel et al. (2007) & $\begin{array}{l}\text { Wave height reduction between 5 to 7.5 } \\
\text { times larger than plain seabed }\end{array}$ & \\
\hline $\begin{array}{l}\text { Tuyen and Hung } \\
(2009)\end{array}$ & $80 \%$ wave height reduction & $\begin{array}{l}\text { Width: 200 m or twice the } \\
\text { wavelength }\end{array}$ \\
\cline { 2 - 3 } Mensly planted \\
\hline \multirow{2}{*}{$\begin{array}{l}5 c I v o r \text { et al. (2012) } \\
\text { kilometer mangrove forest }\end{array}$} & $\begin{array}{l}\text { Wind and swell waves reduction greater } \\
\text { than 75\% }\end{array}$ & Planted in over large areas \\
\hline
\end{tabular}

Mazda et al. (2006) examined several plant species in a mangrove biome and found different influences on wave height among the genera. A reduction in wave height is found for genera with pneumatophores, for example any plants from the Rhizophora species. Compared to other mangrove types, Rhizophora spp. are the most favourable for wave attenuation (Hadi et al. 2003, Kathiresan and Rajendran 2005, Mazda et al. 2006, Tanaka et al. 2007). The dense and strongly connected roots also inhibit coastal erosion as well as accumulate and build up sediments, thus serving indirectly as a coastal protection measure (Gedan et al. 2011). The occurrence of Rhizophora species, however, differs for certain areas; while they grow seaward around India, they are found more landward in Southeast Asia (Kathiresan and Rajendran 2005).

Mangroves will not prosper on sandy soils with low humus content as well as low freshwater runoff or high salt concentrations. They lose stability when they are uprooted or bent. Uprooting is influenced by local bathymetric and geographical characteristics as well as the soil properties (Strusinska-Correia et al. 2013). Yanagisawa et al. (2009) found a correlation between survival rates after tsunamis and stem diameter of Rhizophora trees. Once a tree is uprooted in storm or flood events, it will become a dangerous debris itself. Nonetheless, a mangrove forest can completely regenerate after destruction within 15-30 years (EJF 2006).

In summary, in terms of coastal protection, mangroves can be restored together with conventional coastal protection measures and decrease the impact on conventional protection structures, thus reducing the dimensions required for such structures (Tuyen and Hung 2009). Mangroves shelter the hinterland from coastal hazards as stand-alone measures if sufficient space is provided (Harada et al. 2002, Barbier et al. 2013).

\subsubsection{Ecological Benefit}

Ecologically, conserving and restoring mangrove trees is important to reduce effects of climate change. They are regarded as important carbon sinks and thus contribute effectively to minimise greenhouse effects. One hectare of mangrove forest can extract approximately 1.5 tonnes of carbon per year from the atmosphere. For Indonesia 1.82 million ha of mangrove forest are available, leading to an equivalent reduction of exhaust gases from more than five million cars (GIZ 2011). 
Additionally, the sediments beneath the mangrove trees keep another 700 tonnes of carbon per hectare by retaining the alluvial river sediments and tree leaves from upstream (see Fig. 4). The material is held back in the roots of mangrove trees and becomes solved organic matter in the tree's bed. Therefore, mangrove forests literally serve as carbon filters for (river) water. Mangroves also remove contaminants from the ocean and waterways (GIZ 2011). However, a clearance or die-off of a mangrove area will again release the stored pollutants.

By accumulating sediments and building upward, mangrove trees can adapt to changes in water levels, which is a decisive feature to keep pace with sea level rise. However, the plants can only respond to a limited, moderate rise of water levels (Vedharajan and Gross 2007).

In addition to coastal protection, mangroves secure the livelihood of the surrounding population by providing services such as firewood, medicines, fibres, dye and even food. They also serve as habitat and breeding ground for many fishes and animals, including shrimps, birds and marine mammals (GIZ 2011). Vedharajan and Gross (2007) estimated the economic value of mangrove forests to be around 7,000 Euros per hectare, calculating without carbon storage.

A successful implementation with mangroves as sediment trap was made by the Research and Development Centre for Marine and Fisheries Technology, Jakarta (KKP-P3TKP) on the coast of Kamal Muara across from the Kamal Pantai Fish market in North Jakarta (Andayani et al. 2013). Before their installation, the seaward bank of the adjacent shrimp ponds were at risk of breaking due to high erosion rates. The team of KKP-P3TKP installed geotubes at the Kali Kamal river mouth to decrease flow velocity locally and planted mangrove trees on the lee-side of the tubes, which stabilized the banks successfully.

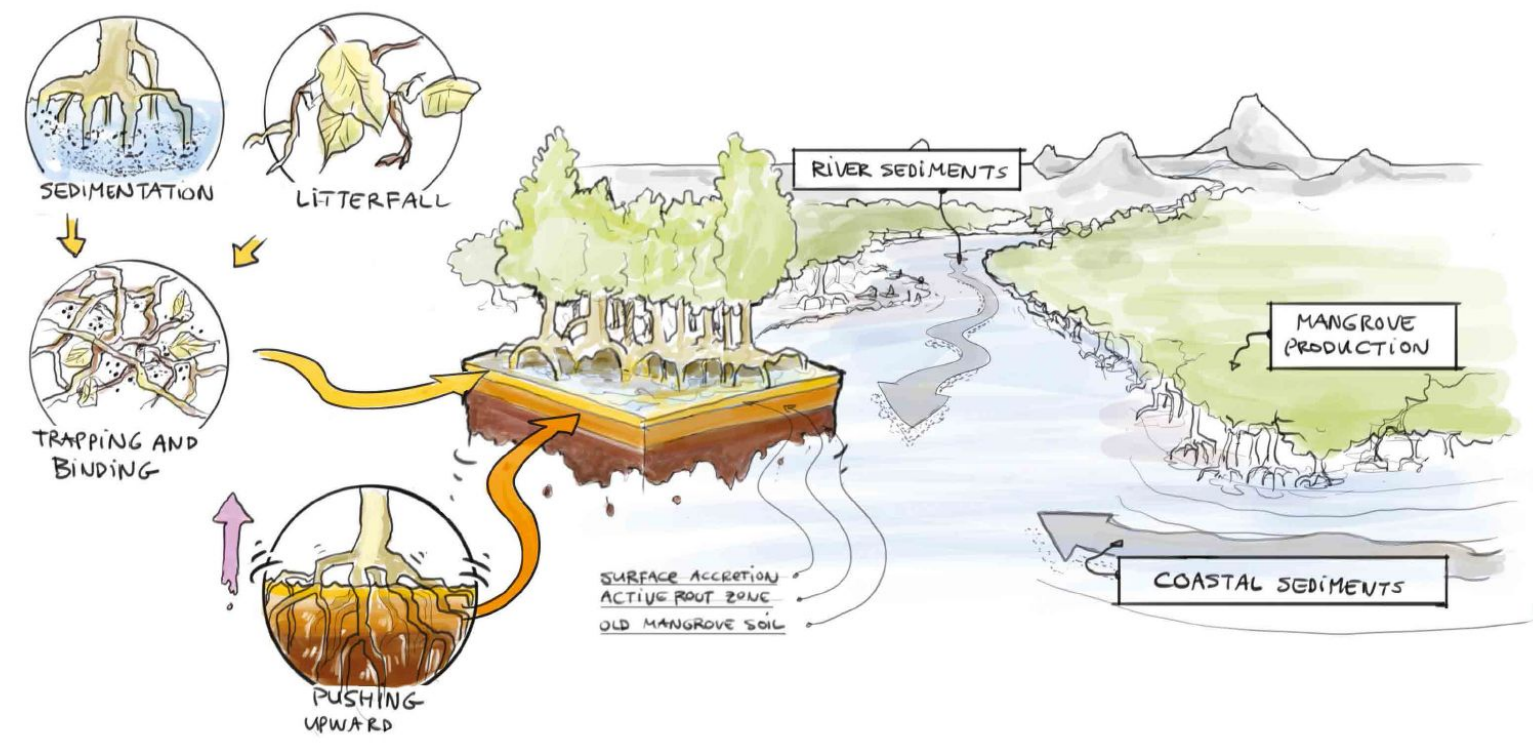

Fig. 4 Principle of sediment accumulation and filter capability of mangroves [taken from Spalding et al. 2014; reproduced with permission] 
Coir fiber geotextiles are a cost-effective, biodegradable and sustainable building material, following the paradigm of building with nature. They stabilize high slopes and banks of soil structures by ecological measures. Coir geotextiles support initial soil consolidation and protect early cultivation of vegetation, and consequently strengthens banks or dykes, eliminating the need for a permanent and persistent synthetic solution (i.e. hard revetment).

Coir is a seed fiber and a waste product of the food industry. The fibers are lignocellulosic ${ }^{2}$ fibers, which are gained from the cortex or husk of the coconut fruit (see Fig. 5). The coir fiber has low cellulose but high lignin content. Low cellulose content is in general responsible for poor mechanical properties, while increased lignin content stiffens and toughens the fiber (Silva et al. 1999) and leads to higher resistance to weathering, fungi and bacteria (Carus et al. 2008). Coir fibers undergo biological degradation, but at a much lower rate compared to other natural fibers (Silva et al. 1999, Lekha 2004, Lekha and Kavita 2006, Carus et al. 2008). Coir contains the highest microfibrillar angle among typical natural fibers, which is a property of the microstructure of wooden fibers. The microfibrillar angle describes the orientation of the helical windings of fibers against the longitudinal cell axis and is critical factor for physical and mechanical resistance of wood (Cave 1994), where a high microfibrillar angle leads to a high tensile strength (Miller et al. 1998, Silva et al. 1999).

There is no universally valid lifetime for coir fibers, as the endurance of natural (geo-) textiles depend on a wide variety of environmental factors on site, but there are studies regarding their strength and site-specific lifetime: On the one hand, there are quantified measures (i.e. Balan and Venkatappa Rao 1996, Miller et al. 1998, Lekha 2004, Marques et al. 2014) measuring a loss of tensile strength of 55\% to almost $80 \%$ after 6 to 7 months. On the other hand, there are measures by experience: Rajagopal and Ramakrishna (2009) give their coconut-based geotextiles a total life span of four years. Miller et al. (1998) speak of a 7-year design lifetime, which they also recognized as a commonly-used value in the early applications of coir fiber geotextiles. However, a reduction of tensile strength does not include a reduction of other stability attributes. The initial strength will decrease rapidly after the first few months, but decay rates will then be much lower.

\footnotetext{
${ }^{2}$ Lignocellulose: Cell walls of wooden plants, which consist of hemicellulose, cellulose and lignin.
} 


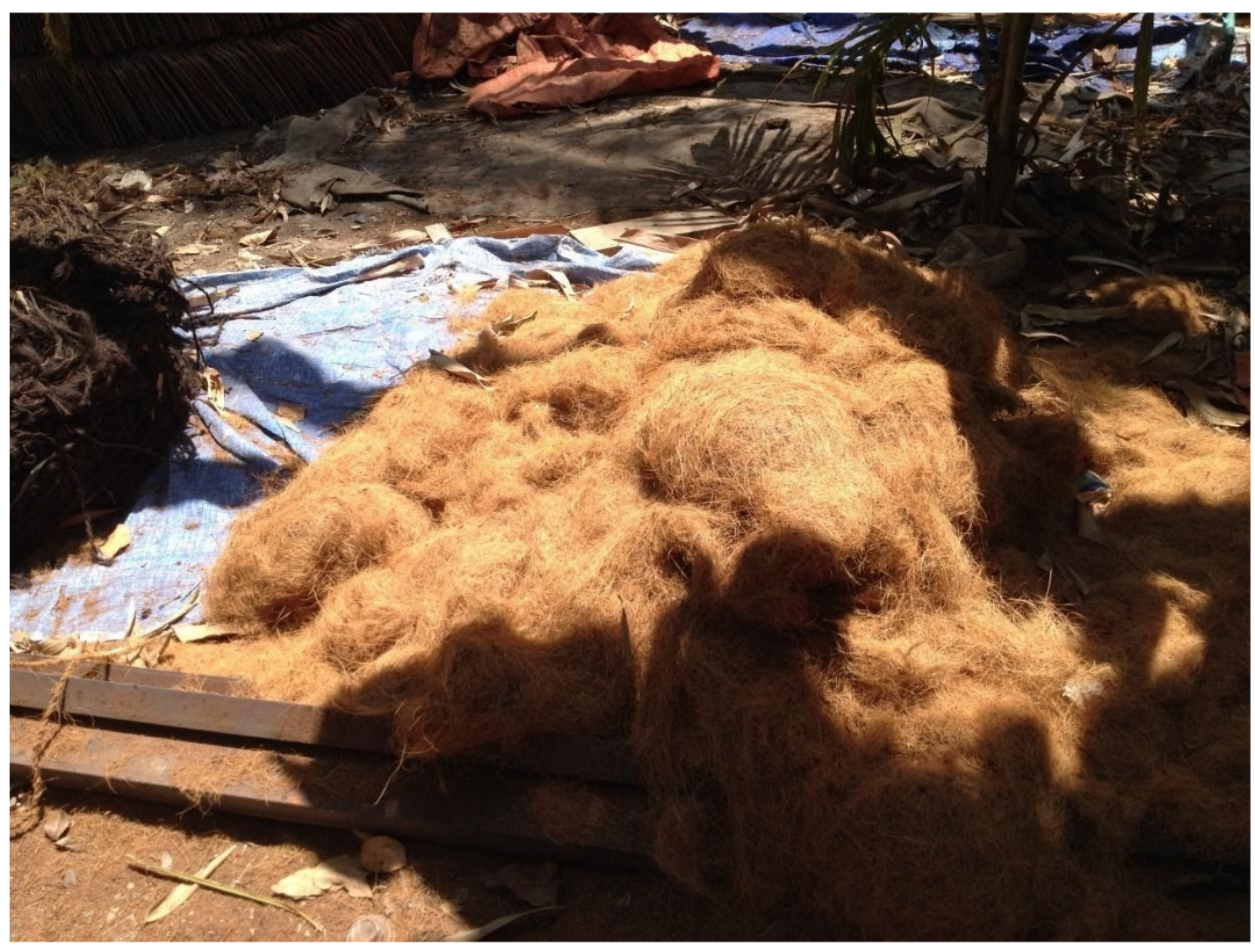

Fig. 5 Extracted coir fibers, the raw material for coir products such as geotextiles, (C) David 2014

\subsubsection{Application}

A test field investigated by the authors of coir-geotextiles for coastal engineering is located on Tabanan Beach, south shore of Bali Island, Indonesia. Tabanan is located northwest of Denpasar, and the areas surrounding the beach are experiencing rapid changes in land use from rice fields as well as from tourism-related infrastructures. The south shore of Bali is prone to wave attack and erosion. The test site is bounded by two volcanic rock peninsulas with groyne-like features, reducing long-shore sediment transport. Yet wave attack in storm conditions still causes considerable cross-shore sediment transport and thus erosion. The beach, however, will be a considerable economic asset due to the anticipated increase in tourism. Therefore, a compromise of beach preservation and coastal protection has to be found and, as of today, two approaches are being considered by the local government:

- Hard-structured concrete seawalls on the eastern part of the test site (Fig. 6). The seawall protects a parking lot and nearby lodges and homes. Other seawalls under similar conditions protect the area behind the structure, but have led to or increased erosion problems on the beach.

- The coir geotextile protected dune head is located further north than the hard-structure. The dune base is secured by bamboo sticks. Behind the sticks are two coir rolls and the dune body. The rolls and the dune body are wrapped by coir geotextiles. The installation can be seen in Fig. 7 and Fig. 8. After being installed, vetiver grass is planted on the dune to reinforce the soil. 
As both approaches are just being implemented at the time of writing, a direct comparison is not immediately possible.
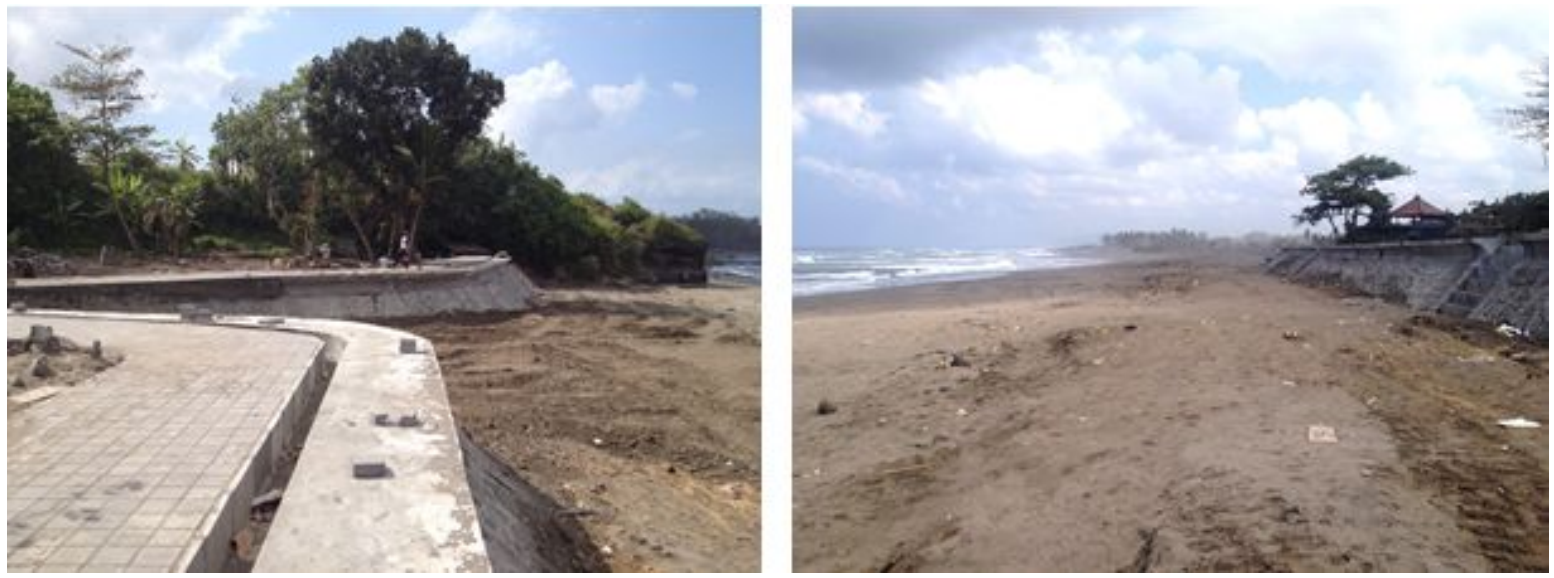

Fig. 6 Hard-structure seawall in Tabanan, Bali (C) David,2014

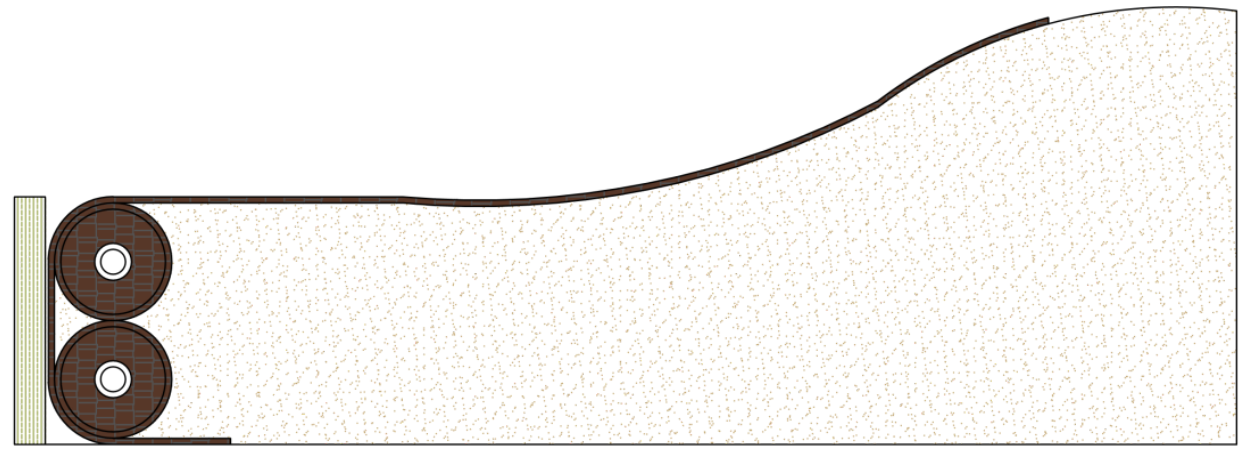

Fig. 7 Schematic sketch of coir fiber geotextile installation. On the left is the bamboo stick support, followed by two coir rolls and the dune body, which together with the rolls is wrapped in a geotextile layer 

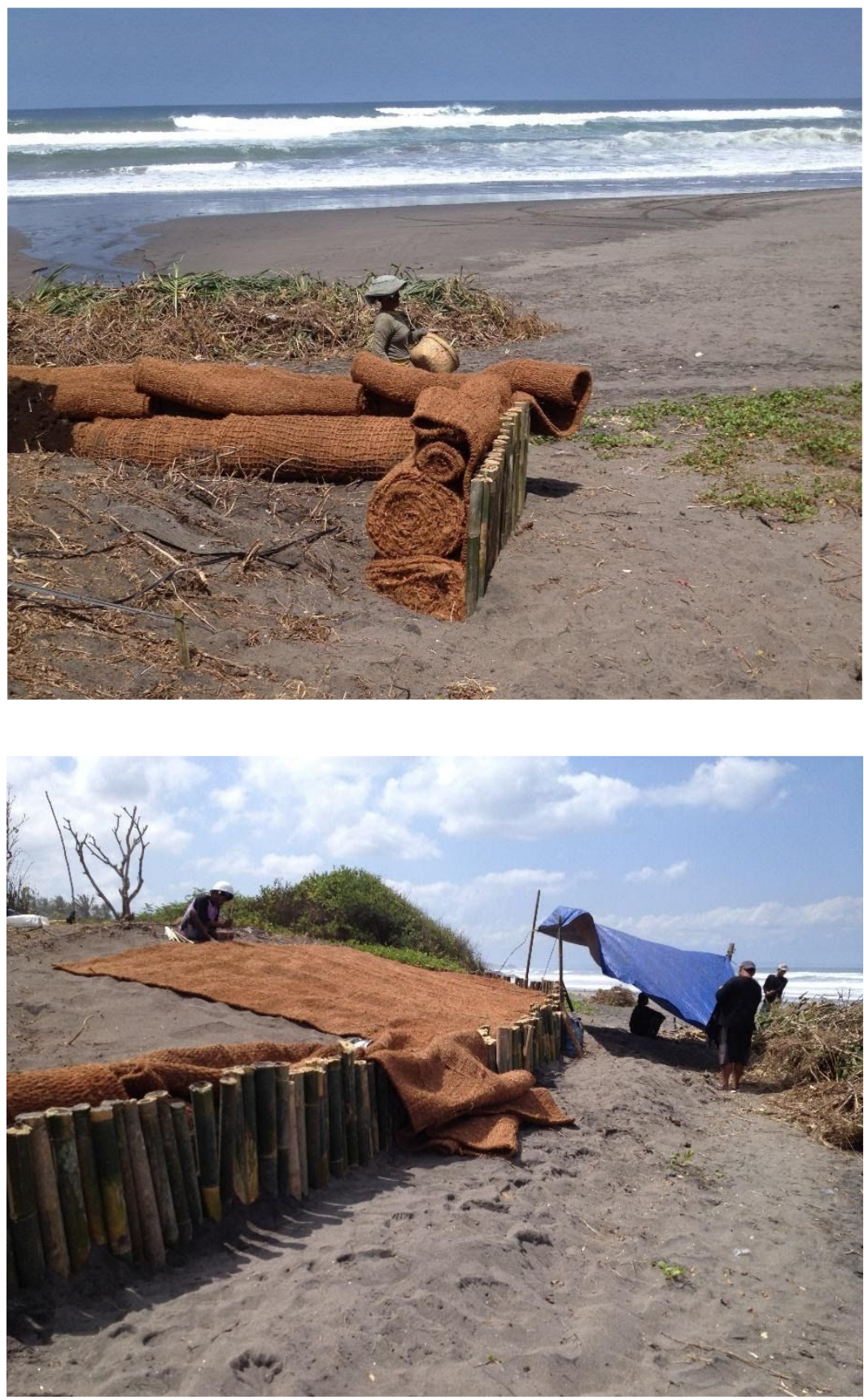

Fig. 8 Pictures of the on-site coir geotextile installation. The upper picture shows the cross-sectional view on the textiles. The bottom picture shows the bamboo wall and the installation of the top coir layer. (C) David 2014 
In practice, coir fibers are used as temporary alternatives to non-degradable synthetic geotextiles to prevent erosion and deformation, support bank stability, facilitate consolidation processes and drainage, with the aim to reinforce soil structures (Miller et al. 1998, Lekha and Kavitha 2006). Lekha and Kavitha (2006) for example use natural coir products in wetland areas, as water-permeable filter, preventing early structural failure during the consolidation process. Rajagopal and Ramakrishna (2009) and Subaida et al. (2009) studied coir textile application for rural roads. Miller et al. (1998) and Lekha (2004) studied the influence of coir geotextiles with regard to bank stability and erosion prevention. Both suggest a hybrid method of geotextiles with subsequent planting of, for example beach grass or vetiver. The geotextile supports the initial stability of the bank or dyke structure while the coir netting provides shelter for rain impact. After germinating, the seeds will grow through the coir netting, while the degrading natural coir material turns from covering shelter to nutrient supplier. Coir has also been successfully applied outside of Southeast Asia, for instance in Europe (Schurholz 1991) and India (Balan and Venkatappa Rao 1996).

Faruk et al. (2012) mentioned their lack of consistency of fiber properties and processing conditions and the fibers' sensitivity to weathering as major drawbacks of coir fibers. The latter condition, however, can be improved. A test by Miller et al. (1998) proves that degradation rates due to weathering (e.g. UV radiation, moisture and temperature) under temperate continental climate conditions led to tensile strength decrease to only $<1 \%$ for longitudinal loads and $9 \%$ for transverse loads of the initial strength after 6 months. This confirms an influence of weathering on fiber degradation, but in comparison to degradation rates by soil-fiber interactions, coir fiber degradation rates are rather low (see Miller et al. 1998, Balan and Venkatappa Rao 1996, Lekha 2004, Rajagopal and Ramakrishna 2009, Marques et al. 2014).

\subsection{Submerged Protection Structures}

Most erosion problems encountered are the consequence of anthropogenic re-working of shorelines and the interference with natural sediment fluxes and alteration of sediment budgets (e.g. groins interrupting longshore sediment transport). In natural conditions, storm events subtract sediment material offshore, while swell waves steadily and slowly nourishes the beach again during low energy periods (Silvester and Hsu 1997, USACE 2002, Komar 1976). This process requires a natural margin for the coast to move between swell and storm seasons. Nevertheless, given that ocean view and beach connection are attractive for domestic or touristic properties, seaside constructions are mostly located closely to the coastline or directly on the shoreline and thus disturb the natural margin of sediment movements. Likewise, poorly-managed coastal development, deviation of freshwater streams and river damming or intense aquaculture (e.g. shrimp cultivation) aggravate erosion problems. Two potential solutions are artificial reefs or permeable submerged breakwaters. They reduce cross- and longshore erosion by reducing wave energy to overcome adverse erosion effects and recreate a natural operating space for sediment transport (e.g. Burcharth et al. 2007). If properly designed, they will protect the shoreline as well as support and conserve the coastal ecosystem by mimicking a natural near-shore habitat.

\subsubsection{Low-crested and Submerged Breakwaters}

Submerged breakwaters are a special type of the traditional engineering breakwater measure, which are classified as hard protection measures, for example for port protection. Emerged breakwaters are a simple bar aiming to reduce wave heights. Sedimentation or scouring as a result of the breakwater is 
almost unavoidable and leads to high dredging costs, but calm water is the top priority for port efficiency and safety, thus justifying these expenses (Burcharth et al. 2007).

If aesthetic aspects of the protection measure have to be considered as well, for example on tourist beaches, submerged breakwater solutions become more attractive. Conventional, impermeable submerged breakwaters are equal in construction principles and material to normal breakwaters, only with their berm underneath the water level. If planned properly, they can be designed to decrease long-shore sediment transport by bending oblique incident waves by refraction and to reduce cross-shore sediment transport. Reduced cross-shore sediment transport then initiates tombolo or salient formation.

Submerged breakwaters affect waves by dissipation, transmission and reflection (e.g. Oumeraci et al. 2001). Energy dissipation is induced by wave breaking, friction or other non-linear interactions (i.e. Mason and Keulegan 1944, Roeber et al. 2010), leading to decreased wave height and changed wave form (Habel 2001, Bleck and Omeraci 2004). Wave attenuation depends primarily on the reef water depth and its width relative to the wave length (e.g. Oumeraci et al. 2001) and performs differently for changing sea water levels. Lowe et al. (2004) also indicate bottom friction as important factor for wave attenuation, but its importance varies depending on studies (Thornton and Guza 1983, Young 1989, Massel and Gourlay 2000). Non-linear interactions are also induced by submerged structures and transfer wave energy into higher harmonics or lower periods.

Wave energy depends on wave height $(\mathrm{H})$ and wave period $(\mathrm{T})$, thus decreasing if wave heights or wave periods decrease. This attenuation leads to decreased sediment transportation (Oumeraci et al. 2001, UNEP 2010), which can be further enhanced by a combination of artificial reefs, beach nourishment and groynes (Bleck and Omeraci 2004, Schlurmann et al. 2004). Wave energy transfer shows also significant effect on the longshore morphodynamics ${ }^{3}$ (e.g. Hsu and Evans 1989, Gonzalez and Medina 2001, Cánovas and Medina 2012).

Transmission can be described by the wave transmission coefficient $\mathrm{K}_{\mathrm{t}}=\mathrm{H}_{\mathrm{T}} / \mathrm{H}_{\mathrm{i}}$ with $\mathrm{H}_{\mathrm{T}}$ as transmitted wave height and $\mathrm{H}_{\mathrm{i}}$ as incident wave height. Dattatri et al. (1978) studied several submerged breakwater types and their ratio of crest submergences $\left(d_{S}\right)$ to water depth $(d)$, to derive performance characteristics for the transmission coefficient. They found that for $\mathrm{d}_{\mathrm{s}} / \mathrm{d}=0.4$, the transmission coefficient can be in the order of $75 \%$ to $95 \%$. Habel (2001) introduced a concept of 2 to 4 layers submerged filter modules with $\mathrm{K}_{\mathrm{t}}$ over $70 \%$ to $80 \%$ of initial wave energy. Arnouil (2008) compiled several design criteria, for successful submerged breakwater design. The result distinguishes between tombolo and salient formation. Tombolos are created by accumulated sand on the lee-side of the breakwater, which attach the structure to the coast. Salients do not reach to the breakwater and allow further longshore sediment transport. The latter are favoured as mentioned by Chasten et al. (1993) and USACE code EM 1110-2-1617 (USACE, 2002); otherwise, downstream beaches will be cut off from sand supply and will most likely erode (faster).

Reflection of the incident waves is described by the reflection coefficient $K_{r}=H_{R} / H_{i}$ with $H_{R}$ as reflected wave height. Wave reflection influences neighbouring structures and scouring around the structure itself for reflection coefficients larger than 25\% (Omeraci et al. 2001). Therefore, a small reflection coefficient is favourable. Scouring can also occur on each end of multiple submerged

\footnotetext{
${ }^{3}$ Morphodynamics: The dynamic interaction of seabed material with hydrodynamic processes as waves, tides and currents, which leads to erosion or sedimentation.
} 
breakwaters with low permeability, which require gaps between each other to maintain water circulation. However, these gaps can create rip-channels with high currents, leading to erosion.

Lower reflection and locally accumulated backflow coefficients as well as increased dissipation and transmission can be achieved by permeable structures e.g. on filter elements (Omeraci et al. 2001), plugged block modules (Habel 2001) or artificial reefs.

\subsubsection{Artificial Reefs}

A reef is per definition a strip, bar or ridge of seabed material rising shortly beneath the water surface. Natural reefs can consist of rock and sand as well as coral or algae. Artificial reefs exist in several forms and types with a wide range of complexity and sophistication. Building materials vary from recycled natural material to more elaborate structures, for instance piled up sand containers made out of geotextiles or concrete elements. First experiences with artificial reefs where made in Japan and date back to the 1950s, while research started to focus on the topic in the 1960 s (i.e. Carlisle et al. 1964).

Artificial reefs are a combination of submerged breakwaters and natural reefs. They are designed as an artificial submerged structure which mimics the protection potential and ecological benefits of a natural reef (UNEP 2010, Goreau and Trench 2012). Artificial reefs can provide multiple services in addition to coastal protection. For example, Mendonca et al. (2012) use numerical models to design an artificial near-shore reef for erosion protection and improve surfing conditions. Furthermore, the artificial reef will decrease flow velocities and attenuate higher waves, which improves swimming conditions and safety. Near-shore reefs also attract divers, as the reefs are used as shelter by multiple fish and marine animals. Altogether, these factors can potentially increase local tourism (Bleck and Omeraci 2004).

Reefs also serve as shelter and habitat for algae and small fish, which then again attract bigger fishes. Reefs thus increase the ecosystem resilience (i.e. counteract against ecosystem damage) and improve marine biodiversity (Pickering et al. 1997). Whitmarsh et al. (2008) present a positive cost-benefit calculation for artificial reefs due to an increased fish occurrence and determine their monetary value for the local fish industry.

Hence, permeable and porous submerged breakwaters like a bar-type artificial reef are favourable, if sufficiently resistant against wave attack. They combine the protection potential of submerged breakwaters with the ecological benefit and ecosystem services of reef habitats, by mimicking the properties of natural reefs and thereby providing shelter and habitat for smaller fish and plants, thus attracting larger fish and ultimately increasing biodiversity. Under proper environmental circumstances, artificial reefs can potentially attract corals and develop into a coral reef. Martin et al. (2005) investigated submerged breakwaters on European shores (i.e. Spain, Italy and UK) and noticed an improvement of local ecosystem conditions in the form of increased abundance of fish and other species, or the diversity of living organisms. Wehkamp and Fischer (2013) conducted a three-year study in front of Helgoland (Germany) in the North Sea, proving the positive effects of submerged concrete-made tetrapods as a fish nursery ground. A significant increase of fish and juvenile fish abundance surrounding the structures indicates the structures are suitable as a fish nursery ground (Wehkamp and Fischer 2013). Moreover, proper submerged breakwater configuration is used to manipulate wave parameters to improve local surfing conditions (Black and Mead 2009). 
However, Burchardt et al. (2007) also mention constrains, which have to be considered. First of all, there has to be a legal basis for submerged breakwaters in the policy and legislation for coastal protection and sea defence. Bathymetry, a negative influence of artificial structures on vulnerable neighbouring coasts (e.g. by altered sedimentation transport) and the availability of proper building material pose physical limitations for artificial reefs. Finally, Burchardt et al. (2007) encourage a thorough on-site inspection, aiming to identify sensitive sites of historic, natural or environmental value, which could be affected adversely by an artificial interference.

\subsubsection{Application}

Reef Balls ${ }^{\mathrm{TM}}$ are typical concrete modules for artificial reefs. They are offered by the Reef Ball Foundation (RBF 2014), an international, non-profit environmental NGO. Reef Balls ${ }^{\mathrm{TM}}$ are hemispherical fabrics with porous side walls and a hollow body. Fifteen to 40 circular holes in the mantle ensure permeability for sediment and enhances marine habitat (see Fig. 9). The void mimics reef refuge for fishes and provides shelter for sea dwellers, or with smaller holes it can be filled with mud and serves as a mangrove flower pot (RBF 2014). The concrete Reef Ball ${ }^{\mathrm{TM}}$ units are usually produced on-site. RBF (2014) refers to American Society for Testing and Materials (ASTM) standards for the concrete, but individual solutions with alternative local materials have also been successfully applied.

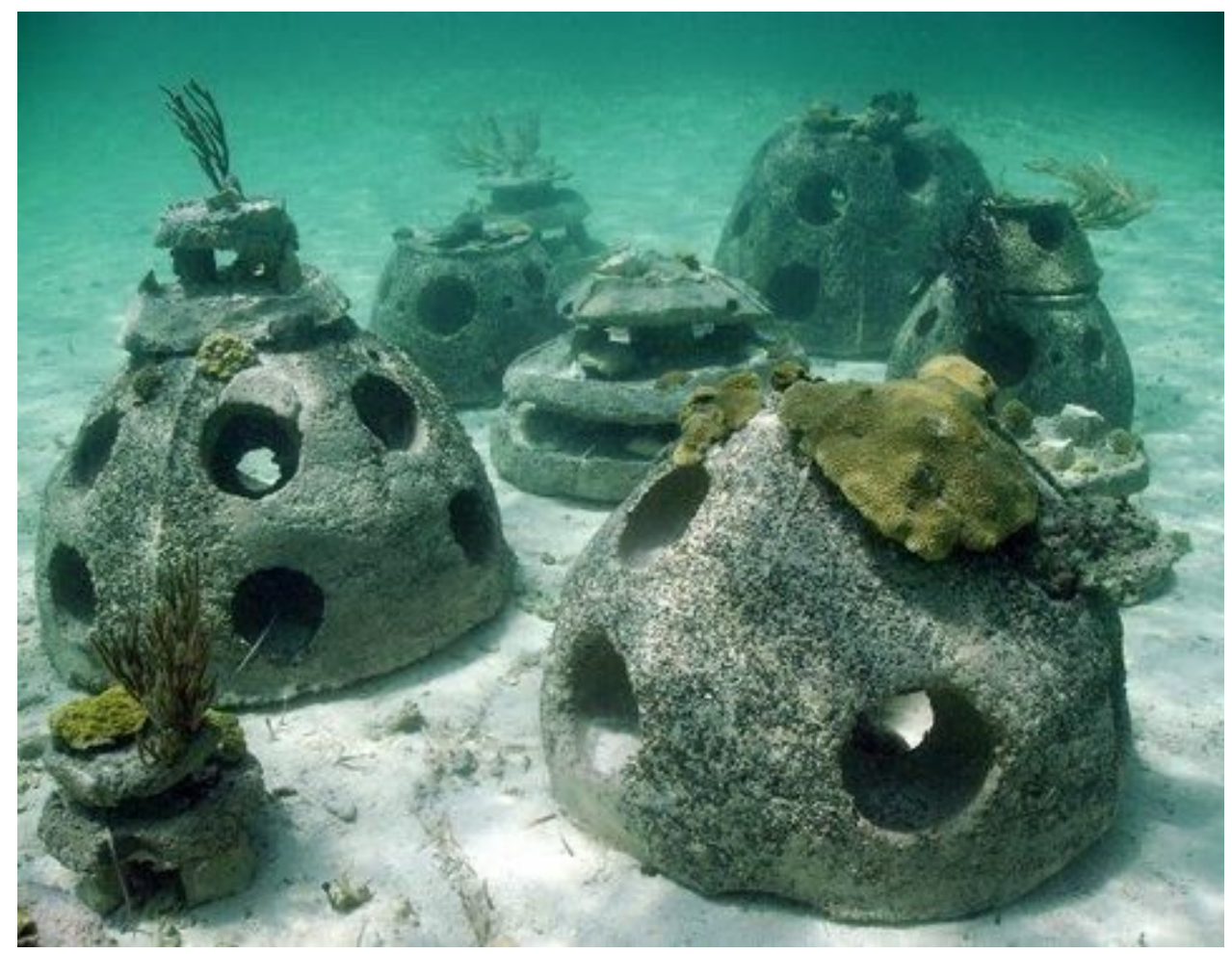

Fig. 9 Newly installed Reef Balls ${ }^{\mathrm{TM}}$ [source: reefball.org; reproduced with permission]

The first use of Reef Balls ${ }^{\mathrm{TM}}$ for wave attenuation and coastal protection was in 1998 in the Dominican Republic (Harris et al. 2004), and since then many other projects have been realized (i.e. USACE 2005, Arnouil 2008). Cesar (1996) estimates the monetary potential for Reef Balls ${ }^{\mathrm{TM}}$ in Indonesia of up to 1 million USD/km for highly developed areas and around 50,000 USD/km for moderately populated areas. Recently, a local Indonesian design has been developed and published 
(Akhwady 2012). It is suitable for Indonesian coastal areas with a price adapted to the Indonesian market. The modules are bottle-shaped porous-hollow cylindrical pieces (see Fig. 10) made from concrete according to Indonesian SNI 7394:2008 standard with a yield strength of $24 \mathrm{MPa}$. The "Bottle Reef" is $1 \mathrm{~m}$ tall, the body has a diameter of $0.9 \mathrm{~m}$, the neck of $0.7 \mathrm{~m}$ and the side walls are perforated with 12 pores. The analysis of a $2 \mathrm{D}$ physical model showed improved $\mathrm{K}_{\mathrm{t}}$ compared to the Reef Ball ${ }^{\mathrm{TM}}$ (Akhwady 2012). Additionally, Bottle Reef can be arranged to minimize gaps between the units and reduce wave energy further, but compared to other reef units, such as the A-Jack, Tetrapod and Cube, Bottle Reef units have the lowest armor stability (Akhwady 2012).

Both Reef Balls ${ }^{\mathrm{TM}}$ and Bottle Reef units were installed at White Sand Beach (Pasir Putih) in Situbondo in Northeast Java Island, separated by approximately $200 \mathrm{~m}$ of each other. Although the former was intended as an artificial reef and was thus approximately $1.5 \mathrm{~m}$ deeper, they have not been damaged by winter storm events and were just slightly displaced, while the Bottle Reef units were completely scattered and several units broke in the first year of field testing. Akhwady (2012) and his research team at the Research and Development Centre for Marine and Fisheries Technology, Jakarta (KKP-P3TKP) and Sepuluh November Institute of Technology, Surabaya (ITS) could not access sufficient funding, making private investment necessary to build the Bottle Reef modules at Pasir Putih Situbondo. Consequently, the units were smaller and of lower quality concrete components, thus light-weight and of weak resistance. Moreover, the budget did not allow monitoring after installation, so that there is no precise data when exactly or under which conditions the Bottle Reef installation failed. Local communities reported a severe storm in early 2014, which most probably was cyclone Gillian and which could have damaged the Bottle Reef.

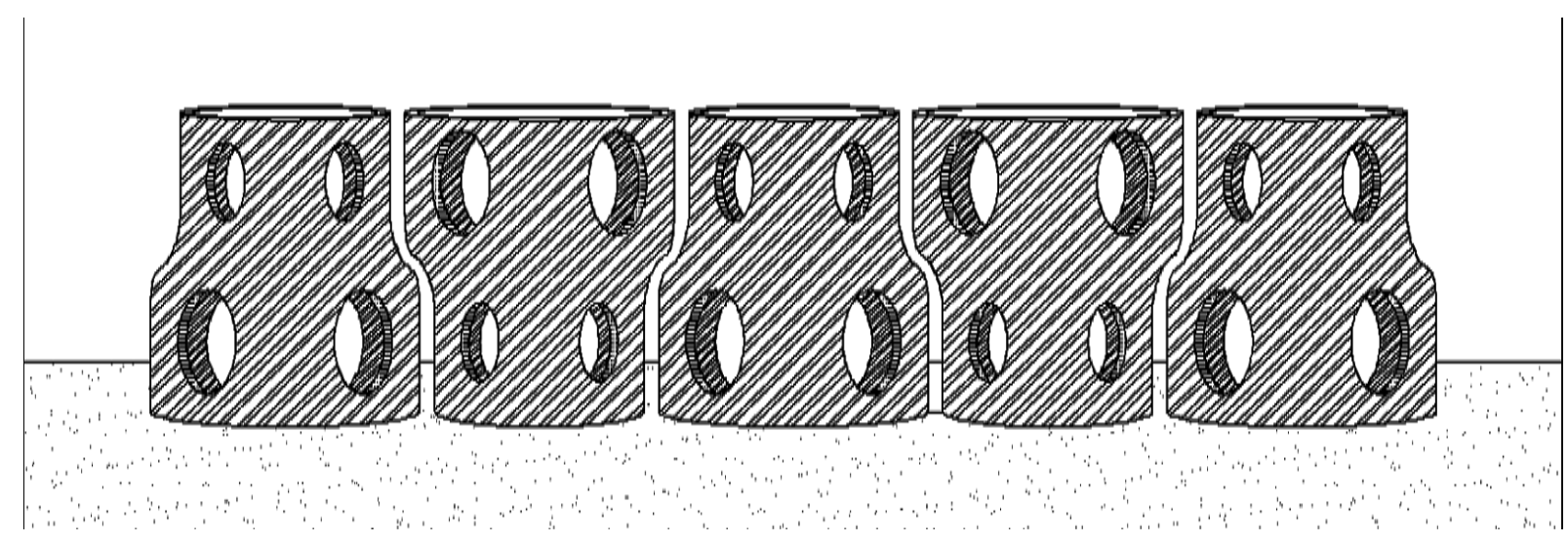

Fig. 10 A series of Bottle Reef units

The added-value and net benefit of artificial reefs or submerged breakwaters is still debated. Without any doubt wave attenuation, erosion protection and improvement of the marine environment are verified in physical, numerical and practical studies, but the application of such systems as an engineering tool is not yet established and doubts with regards to their effectiveness still exist (Scyphers et al. 2011). Baine (2001) and Ranasinghe and Turner (2006) published reviews on the performance of submerged breakwaters and evaluated their feasibility based on literature and their own experiments. The two reviews reached differing conclusions, but both assumed that submerged breakwaters bring benefits to several aspects of the coastal environment. Ranasinghe and Turner (2006) saw the major constraint in poorly understood theoretical principles, which would be necessary to deliver proper combinations of design parameters for a successful artificial reef design. Baine 
(2001) gave an overview of many reef applications and recommends their application, but suggest sound planning and managing. Arnouil (2008) explicitly mentions design parameters for successful implementation of submerged breakwaters.

Another comprehensive overview of "low-crested coastal structures" (LCS) is given in Burcharth et al. (2007). They mention several considerations when building LCS and mention conceptual designs, as well as design parameters. Burcharth et al. (2007) outline a positive effect on sedimentation of submerged (porous) breakwaters, but also mention stagnant water of poor quality on the lee-side of the structures. Additionally they mention the complicated interaction between waves, water levels, currents and sediment transport, making long-term predictions of morphological changes difficult.

Other studies show good results of applied reef bars and submerged breakwaters, but on-site conditions and requirements on the structure have to allow for successful construction and operation (Dean et al. 1997, Habel 2001, Harris et al. 2004). Further examination will gradually close existing knowledge gaps and lead to more practical experience like the Reef Ball Foundation, as well as development of further technologies like the Bottle Reef by Akhwady (2012). The Bottle Reef is still a prototype model and in need of further investigation. To ensure comparable results and create an alternative to more sophisticated externally-developed methods such as the Reef Ball ${ }^{\mathrm{TM}}$, proper funding is essential.

Future research must contribute to understand the underlying, complex physical processes, identify further possibilities, as well as diminish the limitations and constrains of submerged breakwaters. Future results must aim to outline their low-regret characteristics and thus promote a more confident implementation of permeable submerged structures in coastal protection.

\section{Missed Opportunity? Low-regret Solutions not considered in Jakarta's Coastal Defense}

With 250 million inhabitants, some 17,500 islands, $35,000 \mathrm{~km}$ of coastline and a high exposure to natural hazards (among others, a high probability of earthquakes and tsunamis), the Republic of Indonesia is particularly vulnerable to coastal hazards. Jakarta is directly located on the shores of the Java Sea and is crossed by 13 rivers draining into the ocean. Moreover, ground water pumping and subsequently land subsidence have increased drastically in the last decades, resulting in $10.3 \%$ of Jakarta's land area lying below sea level, which will double by 2030 and triple by 2050 according to models by Irzal (2013). Flooding is literally a daily problem for residents during the rainy season, and hazard events as well as exposure will further increase in the future as a result of anticipated sea level rise and more extreme precipitation (IPCC 2012).

Fig. 11 and Fig. 12 illustrate these problems for Northwest Jakarta and North Jakarta, close to the airport and harbour, respectively. The maps were coupled with Shuttle Radar Topography Mission (SRTM) data, describing the area's elevation. The figures show the present coastline as a white, dashed line and the altered coastline in red, if the mean sea level (MSL) rose by $50 \mathrm{~cm}$. 


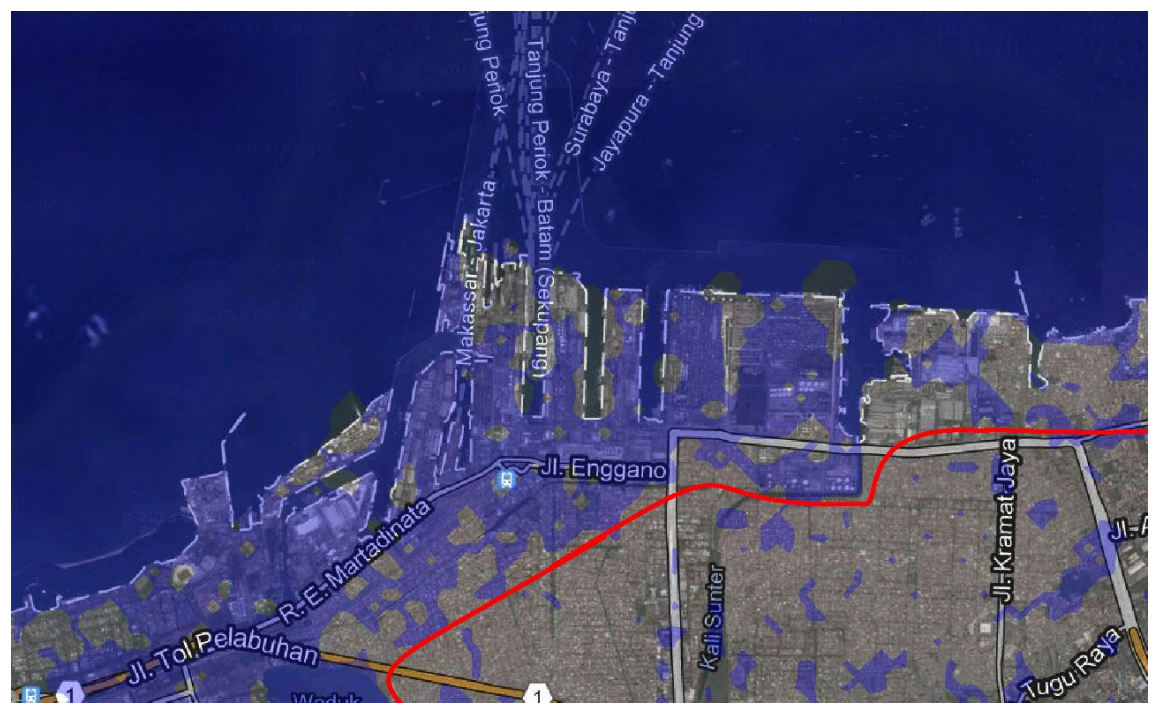

Fig. 11 Static flooding simulation of North Jakarta, port area [map: Google Maps; topographic data: SRTM].

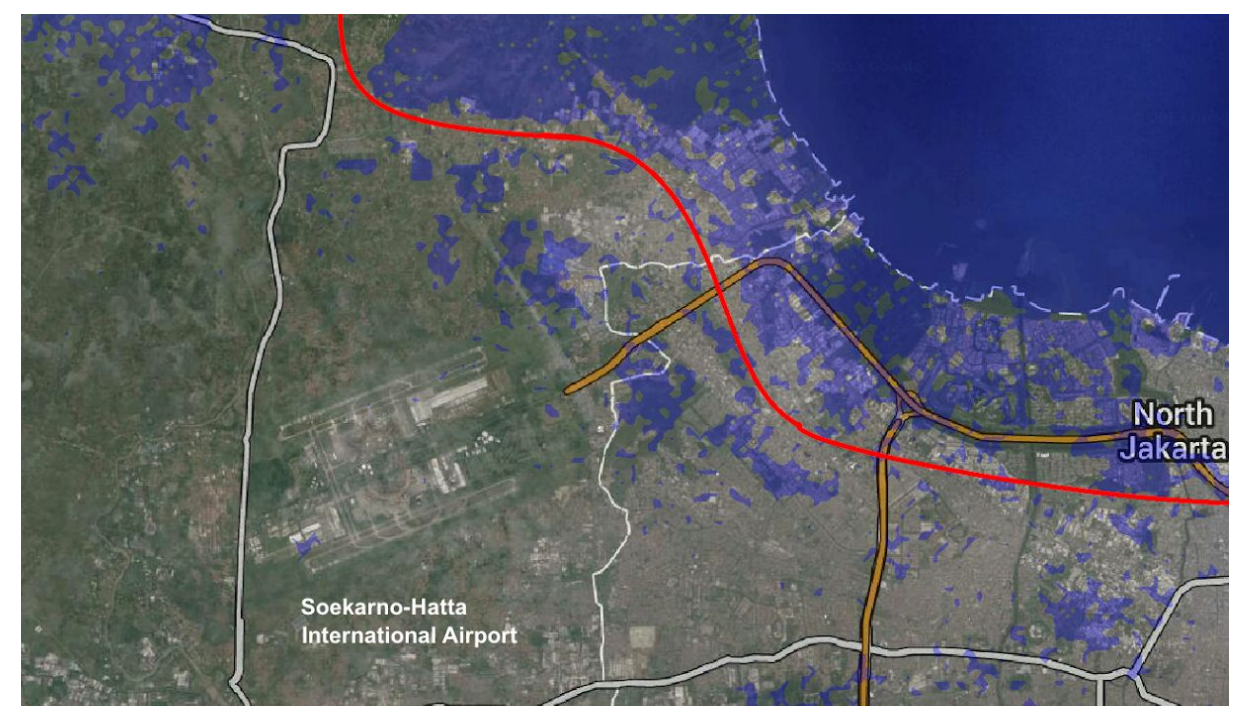

Fig. 12 Static flooding simulation of North Jakarta, airport area [map: Google Maps; topographic data: SRTM].

The disaster risk and need for coastal protection in North Jakarta have become obvious and are addressed by the upcoming National Capital Integrated Coastal Development (NCICD 2014) plan. The plan presents three solutions to tackle Jakarta's flooding problem (NCICD 2014): either abandoning the urban agglomerations (retreat); onshore protection; or seawall protection. The current design chooses the latter option and plans for construction of a dike allowing for traffic, as well as reclaimed offshore islands similar to the Palm Islands in Dubai. These islands will have the shape of Indonesia's heraldic symbol, the Garuda and will be created in the bay of Jakarta. The Jakarta barrier will extend along Jakarta Bay and connect the northern parts of east and west Jakarta, thus aiming to reduce the city's problem of congestion and urbanisation. However, the islands are man-made dikes, coming at cost of putting in place a proper ICZM. The plan misses an opportunity to use modern ecosystem-based disaster risk reduction (Eco-DRR) approaches, which could offer sustainability in an ecological sense, but also yield other benefits. 
NCICD (2014) creates further living space and tries to improve congestion and thus tackles its primary objectives, but the implementation misses a contemporary and modern response to sustainable ecological and social demands. The technical implementation of the land reclamation in the master plan of NCICD (2014) is shown in Fig. 13. The seabed is at $-17.16 \mathrm{~m}$ and goes up to $+7.7 \mathrm{~m}$ at the top of the dike. The bank slope is 1:7, while the top of the dike has a slope of 1:3. Fig. 14 shows an alternative concept, which enhances the initial design with low-regret measures. It proposes a 1:6 slope, which is typical for grass covered sea dykes on the German North Sea coast (EAK 2002 2007). Below mean sea level (MSL), the soil composition of the system in Fig. 14 is equal to the design in NCICD (2014). In shallower water, a berm with artificial reef elements is installed, decreasing wave energy. At MSL, another berm follows, hosting a mangrove belt on muddy soil. The mangroves trap sediments, attenuate waves, and reinforce the soil. The upper part of the alternative protection concept applies coir geotextiles coupled with vetiver grass on a 1:6 and 1:3 slope. The low-regret approach in Fig. 14 uses a $6 \mathrm{~m}$ berm for the artificial reef elements, which is needed for a three-row Reef Ball ${ }^{\mathrm{TM}}$ setup with a diameter of $1.5 \mathrm{~m}, 1.6 \mathrm{~m}$ (Harris 2002) or $1.83 \mathrm{~m}$ per unit Reef Ball ${ }^{\mathrm{TM}}$ and a $20 \mathrm{~m}$ wide berm for the mangroves, allowing for wave energy dissipation of 50-70\% (Vo-Luong \& Massel 2006, 2008). In total, the bank is about $4 \mathrm{~m}$ longer (about 3\% more than the initial design) and requires about $10 \%$ more soil material for construction than the initial design.

Before the final design is published, the different concepts and ideas should have been available to all relevant stakeholders. NCICD (2014) analyses the social impact of the planned sea wall to the community and presents steps to mitigate problems for low-income households and local fishery. However, the master plan misses the opportunity to involve such stakeholders into decision making and consider their expertise and interests in the master plan. Similar as in Rosenzweig et al. (2014), stakeholders and experts should discuss on the basis of a portfolio of adaptation measures, leading to a final design. A broader stakeholder involvement encourages identification and sense of ownership and thus acceptance. It also helps to define competences and jurisdiction among stakeholders in a legal framework, which play a crucial role in reducing disaster risks and which supports resilience significantly (IFRC 2014).

A concept which contains ecosystem-based and local, low-regret measures could have made the master plan a benchmark project for Eco-DRR. However, it misses the opportunity to include local knowledge and apply innovative protection measures that build with nature. 


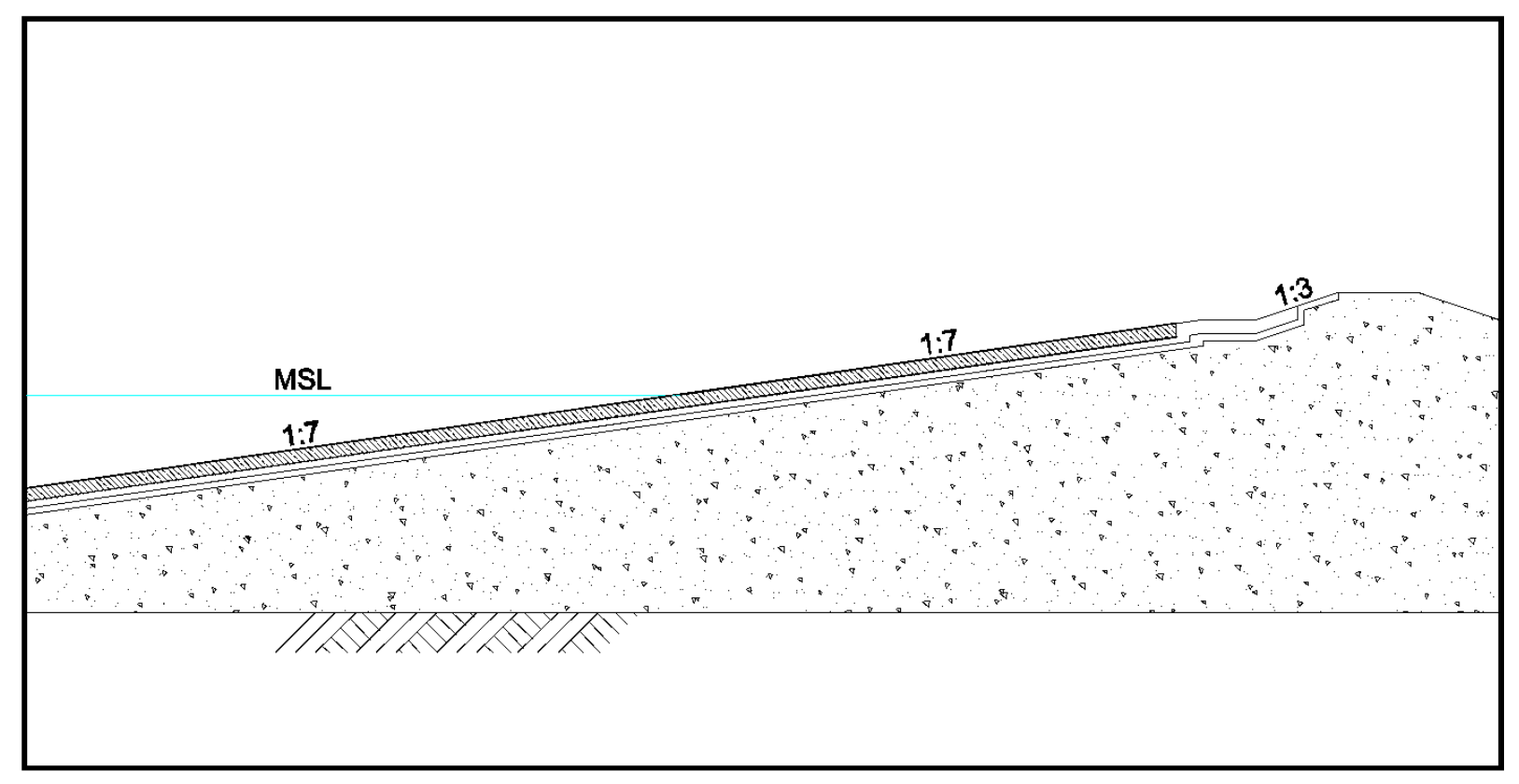

Fig. 13 Cross section of the land reclamation, according to the design of NCICD (2014).

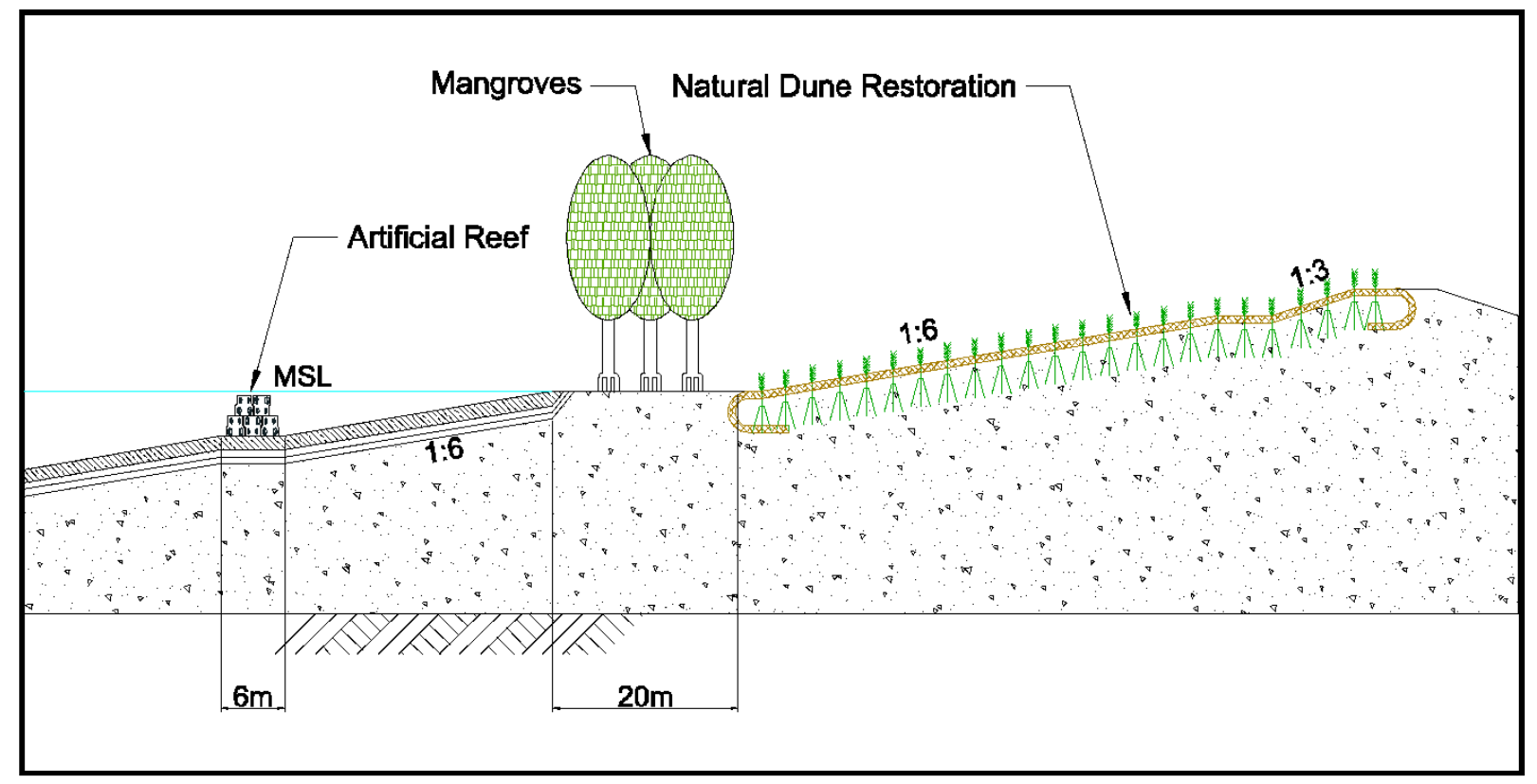

Fig. 14 Cross section of a possible ecosystem based design of the land reclamation. 


\section{Conclusions}

Conventional engineering approaches do not preserve existing ecosystems or support the livelihood of the coastal communities. The integration of socio-economic and marine ecosystem-based approaches into engineering approaches allow for more sophisticated and profitable Ecosystem-based and Low-Regret Adaptation Management (ELRAM), which not only protects the environment from severe hazardous events, but also supports local coastal ecosystems and provides ecosystem services. There are numerous ELRAM-approaches, of which mangroves, natural geotextiles or submerged reefs are just a few examples. Mangroves have proven their efficiency for wave attenuation and sedimentation. However, they grow mainly on muddy soils. Natural coir geotextiles, as an example of the available techniques for dune restoration, initially protect the dunes and support both freshly planted and juvenile dune vegetation until it develops full protection potential. Both mangroves and dunes require physical space to efficiently protect the coastal area. An offshore option for limited space are submerged porous breakwaters, which also could act as artificial reefs if properly designed.

There are a wide variety of methods for coastal protection, of which none is a panacea for Eco-DRR. Mostly they work best in combination with each other (Temmermann et al. 2013). Such combined designs will for many purposes potentially outperform designs, which are based solely on conventional engineering approaches in the future. To increase confidence towards ecosystem-based measures, research must point out the potential of ELRAM-approaches, but also identify limitations and constraints on their suitability. However, the lack of practical experience and knowledge about long-term performance and efficiency prevents a broader application of ELRAM-approaches. Also, the lack of practical guidance, standard of practices and design guidelines hamper its use. To promote the paradigm shift of building with nature and initiate more confident and widespread implementation, knowledge gaps must be filled and scientific findings must lead to practical recommendations and offer design patterns for a successful implementation. 
Akhwady R (2012) Kinerja terumbu buatan silinder berongga (bottle reeftm) sebagai pemecah gelombang ambang terbenam. Phd Dissertation, Insititute of Tenth November Surabaya Indonesia (in Indonesian language)

Andayani A, Soejarwo PA, Indriasari VY (2013) Uji Coba Pemasangan Karung Geotekstil Memanjang (KGM) di Pantai Kamal Muara. (Trial Test of Longitudinal Geotextile Tube Installation in Kmal Muara Coastal Area). Unpublished Report. Pusat Pengkajian dan Perekayasaan Teknologi Kelautan dan Perikanan - BADAN LITBANGKP-KKP (in Indonesian language).

Arnouil DS (2008) Shoreline Response for a Reef Ball ${ }^{\mathrm{TM}}$ Submerged Breakwater System Offshore of Grand Cayman Island. Master thesis, Florida Institute of Technology, Melbourne, Florida.

Augustin LN, Irish JL, Lynett P (2009) Laboratory and numerical studies of wave damping by emergent and near-emergent wetland vegetation. Coast. Eng., 56: 332-340.

Barbier EB, Georgiou IY, Enchelmeyer B, Reed DJ (2013) The Value of Wetlands in Protecting Southeast Louisiana from Hurricane Storm Surges. PLoS ONE 8(3): e58715. doi:10.1371/journal.pone.0058715

Baine MSP (2001) Artificial Reefs: a review of their design, application, management and per-formance. Ocean and Coastal Management 44(3-4):241-259. doi:10.1016/S0964-5691(01)00048-5

Balan K, Venkatappa Rao G (1996) Erosion control with natural geotextiles, Environmental geotechnology with geosynthetics. In: Rao, G.V., Banergee, K. (Eds.), The Asian Society for Environmental Geotechnology and CBIP, New Delhi, pp. 317-325.

Bao TQ (2011) Effect of mangrove forest structures on wave attenuation in coastal Vietnam. Oceanologia, 53(3): 807-818.

Black K, Mead S (2009) Design of Surfing Reefs. Reef Journal 1(1):177 - 191.

Bleck M, Omeraci H (2004) Analytical model for wave transmission at artificial reefs. Proceedings 29th International Conference on Coastal Engineering (ICCE), ASCE, Volume 1, Lisbon, Portugal, pp. 269-281. (PIANC Award 2006 for PhD-thesis).

Bloomberg MR, Burden AM (2013) Coastal Climate Resilience - Urban Waterfront Adaptive Strategies. The City of New York. Department of City Planning.

Bou-Zeid E, El-Fadel M (2002) Climate change and water resources in Lebanon and the Middle East. Journal of Water Resources Planning and Management (ASCE) 128(5): 343-355

Buccino M, Del Vita I, Calabrese M (2014) Engineering Modeling of Wave Transmission of Reef Balls. J. Waterway, Port, Coastal, Ocean Eng. 140(4):04014010 
Burcharth HF, Hawkins SJ, Zanuttigh B, Lamberti A (2007) Environmental Design Guidelines for Low Crested Coastal Structures. Elsevier, Amsterdam.

Cánovas V, Medina R (2012) A Long-Term Equilibrium Beach Planform Model for Coastal Work Design. Coastal Engineering Proceedings 1(33). doi:http://dx.doi.org/ 10.9753/icce.v33.sediment.43

Carlisle JR, Turner CH, Ebert EE (1964) Artificial habitat in the marine environment. California Department of Fish and Game Fish Bulletin 124, 93 p.

Carus M, Gahle C, Pendarovski C, et al. (2008) Studie zur Markt- und Konkurrenzsituation bei Naturfasern und Naturfaser-Werkstoffen (Deutschland und EU). Gülzower Fachgespräche 26, Fachagentur Nachwachsende Rohstoffe e.V. (Hrsg.), Gülzow 2008, S. 126

Cave ID, Walker JFC (1994) Stiffness of Wood in Farown Plantation Softwood: The Influence of Microfibril angle. Forest Product Journal, 4454348

Cesar H (1996) Economic Analysis of Indonesian Coral Reefs. World Bank Environment Department Paper Department, Environmentally Sustainable Development Vice Presidency. December 1996. The World Bank.

Chasten MA, Rosati JD, McCormick JW, Randall RE (1993) Engineering design guidance for detached breakwaters as shoreline stabilization structures. Tech. Rep CERC-93-19. US Army Corps of Engineers Waterways Experiment Station, Vicksburg, Mississippi.

Cheong SM, Silliman B, Wong PP et al. (2013) Coastal adaptation with ecological engineering. Natural climate change 3(9): 787-791

Costanza R, d'Arge R, de Groot R et al. (1997) The value of the world's ecosystem services and natural capital. Nature, 387:253-260.

Costanza R de Groot R, Sutton P (2014) Changes in the global value of ecosystem services, Global Environmental Change, Volume 26, May 2014, Pages 152-158, doi: 10.1016/j.gloenvcha. 2014.04.002

Dattatri J, Raman H, Shankar N (1978) Performance Characteristics of Submerged Breakwaters. Coastal Engineering Proceedings 1(16). doi:http://dx.doi.org/10.9753/icce.v16.\%p

Dean RG, Chen R, Browder AE (1997) Full scale monitoring study of a submerged breakwater, Palm Beach, Florida, USA, Coastal Engineering 29(3-4): 291-315. ISSN 0378-3839

EAK 2002 (2007) Empfehlungen für die Ausführung von Küstenschutzbauwerken - Korrigierte Ausgabe 2007. (Recommendations for Coastal Protection Works - Ammended Edition 2007) Herausgeber (Editor): Kuratorium für Forschung im Küsteningenieurwesen". Die Küste, Heft 65

EJF (2006) Mangroves: Nature's defence against Tsunamis - A report on the impact of mangrove loss and shrimp farm development on coastal defences. Environmental Justice Foundation, London, UK.

Faruk O, Bledzki AK, Fink HP, Sain M (2012) Biocomposites reinforced with natural fibers: 2000-2010. Progress in Polymer Science 37(11):1552-1596

Gedan KB, Kirwan ML, Wolanski E et al. (2011) The present and future role of coastal wetland vegetation in protecting shorelines: Answering re-cent challenges to the paradigm. Climatic Change 106:7-29. 
GIZ (2011) Mangroves. Deutsche Gesellschaft für Internationale Zusammenarbeit (GIZ) GmbH.

Gonzalez M, Medina R (2001) On the application of static equilibrium bay formulations to natural and man-made beaches. J. Coast. Eng. 43:209 - 225

Goreau TJ, Trench RK (2012) Innovative Methods of Marine Ecosystem Restoration, CRC Press, Boca Raton, 5-10

Guannel G,Ruggiero P, Faries J et al. (2015) Integrated modeling framework to quantify the coastal protection services supplied by vegetation, J. Geophys. Res. Oceans 120:324-345, doi:10.1002/2014JC009821.

Harada K, Imamura F, Hiraishi T (2002) Experimental study on the effect in reducing tsunami by the coastal permeable structures. Proceedings of the 12th International Offshore and Polar Engineering Conference. Kita-Kyushu, Japan, May 26-31.

Habel R (2001) Künstliche Riffe zur Wellendämpfung. Berlin (Deutschland, Bundesrepublik), Dissertation, Mensch und Buch Verlag, Berlin 2001, 128 S.; TU Berlin

Hadi S, Latief, H, Muliddin (2013) Analysis of surface wave attenuation in mangrove forest, Proceeding ITB on Engineering Science 35: 89 - 108.

Harris LH (2002) Submerged reef structures for habitat enhancement and shoreline erosion abatement. U.S. Army Corps of Engineers Coastal \& Hydraulic Engineering Technical Note (CHETN), Vicksburg, MS.

Harris LE, Turk G, Mead S (2004) Combined recreational amenities and coastal erosion protection using submerged breakwaters for shoreline stabilization. Beach Preservation Technology 2004, FSBPA.

Hashim AM, Catherine SMP, Takaijudin H (2013) Effectiveness of Mangrove Forests in Surface Wave Attenuation: A Review. Research Journal of Applied Sciences, Engineering and Technology 5(18):4483-4488.

Hiraishi T, Harada K (2003) Greenbelt tsunami prevention in south-pacific region. Report of the Port and Airport Research Institute 42:1-23.

Hsu JRC, Evans C (1989) Parabolic bay shapes and applications. Proceedings Institution Civil Engineers (Part 2.) 87:557 - 570. Thomas Telford, London.

IFRC (2014) Viet Nam: Country Case Study Report - How Law and Regulation Support Disaster Risk Reduction. From: IFRC-UNDP Series on Legal Frameworks to support Disaster Risk Reduction. Geneva.

IPCC (2012) Managing the Risks of Extreme Events and Disasters to Advance Climate Change Adaptation. A Special Report of Working Groups I and II of the Intergovernmental Panel on Climate Change [Field, C.B., V. Barros, T.F. Stocker, D. Qin, D.J. Dokken, K.L. Ebi, M.D. Mastrandrea, K.J. Mach, G.-K. Plattner, S.K. Allen, M. Tignor, and P.M. Midgley (eds.)]. Cambridge University Press, Cambridge, UK, and New York, NY, USA, 582 pp. 
Irzal F (2013) Grey Solutions for Urban Water Management: Jakarta Case. Presented on "C40 Workshop on Climate Adaptation and Risk Assessment" Rotterdam, the Netherlands June 3־6, 2013 http://www.deltacities.com/documents/presentations/ 04\%20Jakarta_CDC\%20website.pdf

Kathiresan K, Rajendran N (2005): Coastal mangrove forests mitigated tsunami. Estuar. Coastal Shelf S 65:601-606.

Komar PD (1976) Beach Processes and Sedimentation, Prentice-Hall, Inc., Englewood Cliffs, NJ

Lacambra C, Friess DA, Spencer T, Möller I (2013) Bioshields: Mangrove ecosystems as resilient natural coastal defenses" in The Role of Ecosystems in Disaster Risk Reduction, edited by Fabrice Renaud, Karen Sudmeier - Rieux, and Marisol Estrella, 82 - 108. Tokyo: United Nations University Press

Lekha KR (2004) Field instrumentation and monitoring of soil erosion in coir geotextile stabilized slopes: a case study. Geotextiles Geomembrances 22:399-413

Lekha KR, Kavitha V (2006) Coir geotextile reinforced clay dykes for drainage of low-lying areas. Geotextiles and Geomembranes 24(1):38-51

Lowe RJ, Falter JL, Bandet MD et al. (2005) Spectral wave dissipation over a barrier reef, J. Geophys. Res.110, C04001. doi:10.1029/2004JC002711.

Marques AR, de Oliveira Patrício PS, dos Santos FS et al. (2014) Effects of the climatic conditions of the southeastern Brazil on degradation the fibers of coir-geotextile: Evaluation of mechanical and structural properties. Geotextiles and Geomembranes, 42(1):76-82

Martin D, Bertasi F, Colangelo MA (2005) Ecological impact of coastal defence structures on sediment and mobile fauna: Evaluating and forecasting consequences of unavoidable modifications of $\begin{array}{llll}\text { native habitats, } & \text { Coastal } & \text { Engineering } & \text { 1027-1051 }\end{array}$ http://dx.doi.org/10.1016/j.coastaleng.2005.09.006.

Mason MA, Keulegan CH (1944) A Wave Method for Determining Depths over Bottom Discontinuities, U.S. Army Beach Erosion Board. Tech. Memo. 5, 29 pp.

Massel SR, Gourlay MR (2000) On the modelling of wave breaking and set-up on coral reefs, Coastal Eng. 39:1-27.

Mazda Y, Magi M, Kogo M., Hong PN (1997a) Mangrove as a coastal protection from waves in the Tong King delta, Vietnam. Mangroves Salt Marshes 1:127-135.

Mazda Y, Wolanski E, King B et al. (1997b) Drag force due to vegetation in mangrove swamps. Mangroves and Salt Marshes 1:193-199.

Mazda Y, Magi M, Ikeda Y et al. (2006) Wave reduction in a mangrove forest dominated by Sonneratia sp. Wetlands Ecol. Manag. 14:365-378. 
McIvor AL, Möller I, Spencer T, Spalding M (2012) Reduction of wind and swell waves by mangroves. Natural Coastal Protection Series: Report 1. Cambridge Coastal Research Unit Working Paper 40. Published by The Nature Conservancy and Wetlands International. 27 pages. ISSN 2050-7941.

Mendez FM, Losada IJ (2004) An empirical model to estimate the propagation of random breaking and non-breaking waves over vegetation fields. Coast. Eng. 51:103-118.

Mendonca A, Fortes CJ, Capitao R et al. (2012) Hydrodynamics around an artificial surfing reef at Leirosa, Portugal. Journal of Waterway Port Coastal and Ocean Engineering 138:226-35.

Miller DE, Hoitsma TR, White DJ (1998) Degradation Rates of Woven Coir Fabric Under Field Conditions. In: DF. Hayes, (ed) Engineering Approaches to Ecosystem Restoration: 266-271; Proceedings of the 1998 Wetlands Engineering and River Restoration Conference, Denver, Colorado, March 22-27, 1998. American Society of Civil Engineers

NCICD (2014) Draft Master Plan. National Capital Integrated Coastal Development Project. Jakarta, Indonesia.

Oumeraci H, Clauss GF, Habel R, Koether G (2001) Unterwasserfiltersysteme zur Wellendämpfung. Abschlussbericht zum BMBF-Vorhaben "Unterwasserfiltersysteme zur Wellendämpfung" (in German).

Pickering H, Whitmarsh D (1997) Artificial reefs and fisheries exploitation: a review of the 'attraction versus production' debate, the influence of design and its significance for policy. Fisheries Research $31: 39-59$.

Quartel S, Kroon A, Augustinus PGEF et al. (2007) Wave attenuation in coastal mangroves in the Red River delta, Vietnam. J. Asian Earth Sci. 29(4):576-584.

Rajagopal A, Ramakrishna S (2009) Coir Geotextiles as Separation and Filtration Layer for Low Intensity Road Bases. Indian Geotechnical Conference (IGC-2009), Guntur, India. Volume II, pp. 941-946

Ranasinghe R Turner IL (2006) Shoreline Response to submerged structures: A review. Coastal Engineering 53:65-79. http://dx.doi.org/10.1016/j.coastaleng.2005.08.003

RBF (The Reefball Foundation) (2014) Webpage: http://www.reefball.org/, last visited Nov. 20th, 2014

Roeber V, Cheung KF, Kobayashi MH (2010) Shock-capturing Boussinesq-type model for nearshore wave processes. Coastal Engineering 57(4):407-423.

Rosenzweig C, Solecki WD, Blake R et al. (2011) Developing coastal adaptation to climate change in the New York City infrastructure-shed: Process, approach, tools, and strategies. Climatic Change 106: 93-127. doi:10.1007/s10584-010-0002-8. 
Schlurmann T, Bleck M, Oumeraci H (2003) Wave Transformation at Artificial Reefs described by the Hilbert-Huang Transformation. Proc. 28th International Conference on Coastal Engineering (ICCE2002), American Society of Civil Engineers (ASCE) 2:1791-1803

Schurholz H (1991) Use of woven coir geotextiles in Europe. Coir XXXV (2):18-25.

Scyphers SB, Powers SP, Heck KL Jr, Byron D (2011) Oyster Reefs as Natural Breakwaters Mitigate Shoreline Loss and Facilitate Fisheries. PLoS ONE 6(8): e22396. doi:10.1371/journal.pone.0022396

Silva GG, De Souza DA, Machado JC, Hourston DJ (1999) Mechanical and thermal characterization of native brazilian coir fiber. Journal of Applied Polymer Science 76(7):1197-1206.

Silvester R, Hsu JRC (1997) Coastal Stabilization. World Scientific Publ. Co., Singapore 578 pp. (Reprint of Silvester and Hsu, 1993).

Spalding M, McIvor A, Tonneijck FH et al. (2014) Mangroves for coastal defence. Guidelines for coastal managers \& policy makers. Published by Wetlands International and The Nature Conservancy. $42 \mathrm{p}$

Strusinska-Correia A, Husrin S, Oumeraci H (2013) Tsunami damping by mangrove forests: A laboratory study using parameterized trees. Natural Hazards and Earth System Sciences 13: 483-503

Subaida EA, Chandrakaran S, Sankar N (2009) Laboratory performance of unpaved roads reinforced with woven coir geotextiles. Geotextiles and Geomembranes 27: 204-210

Suzuki T, Zijlema M, Burger B, Meijer MC, Narayan S (2012) Wave dissipation by vegetation with layer schematization in SWAN, Coastal Engineering, Volume 59, Issue 1, January 2012, Pages 64-71, ISSN 0378-3839, http://dx.doi.org/10.1016/j.coastaleng.2011.07.006.

Tanaka N, Sasaki Y, Mowjood MIM et al. (2007) Coastal vegetation structures and their functions in tsunami protection: Experience of the re-cent Indian Ocean tsunami. Landscape Ecol. Eng. 3:33-45.

Taubenböck H, Goseberg N, Lämmel G et al. (2013) Risk reduction at the "Last-Mile": an attempt to turn science into action by the example of Padang. Natural Hazard 65:915-945

Temmerman S, Meire P, Bouma TJ et al. (2013) Ecosystem-based coastal defence in the face of global change. Nature 504(12):79-83. doi:10.1038/nature12859.

Teo FY, Falconer RA Lin B (2009) Modelling effects of mangroves on tsunamis. Water Manage. 162: $3-12$.

Thornton EB, Guza RT (1983) Transformation of wave height distribution, J. Geophys. Res. 88:5925-5938.

Tuyen NB, Hung HV (2009) An experimental study on wave reduction efficiency of mangrove forests. Proceeding of the 5th International Conference on Asian Pacific Coasts (APAC2009). Nanyang Technological University (NTU), Oct.13-16, Singapore, 4: 336-343. 
UNEP (2010) Linking ecosystems to risk and vulnerability reduction. The case of Jamaica. UNEP: Geneva. See also: http:postconflict.unep.ch/publications/RiVAMP.pdf

USACE- U.S. Army Corps of Engineers (2002) Coastal Engineering Manual. Engineer Manual 1110-2-1100, U.S. Army Corps of Engineers, Washington, D.C. (in 6 volumes).

USACE- U.S. Army Corps of Engineers (2005) National Erosion Control Development and Demonstration Program (Section 227) Miami Beach, Florida.

Vedharajan B, Gross O (2007) MANGREEN - Mangrove Ecology and Restoration in India. REPORT 2006/07 (DEEPWAVE Report 09/07), 40 p.

Vo-Luong P, Massel SR (2006) Experiments on wave motion and suspended sediment concentration at Nang Hai, Can Gio mangrove forest, Southern Vietnam. Oceanologia 48(1):23-40.

Vo-Luong P, Massel S (2008) Energy dissipation in non-uniform mangrove forests of arbitrary depth. Journal of Marine Systems 74(1-2):603-622.

Wehkamp S, Fischer P (2013) Crustaceans and fish abundances and species at and around artificially introduced tetrapod fields in the southern North Sea, 2013. Alfred Wegener Institute for Polar and Marine Research - Biological Institute Helgoland, doi:10.1594/PANGAEA.821916

Whitmarsh D, Santos MN, Ramos J, Monteiro CC (2008) Marine habitat modification through artificial reefs off the Algarve (southern Portugal): An economic analysis of the fisheries and the prospects for management. Ocean. Coast. Manage. 51:463-468.

Wilby RL, Keenan R (2012) Adapting to flood risk under climate change. Progress in physical geography 36(3):348-378

Yanagisawa H, Koshimura S, Goto K et al. (2009) The reduction effects of mangrove forest on a tsunami based on field surveys at Pakarang Cape, Thailand and numerical analysis. Estuar. Coastal Shelf S. 81:27-37.

Young IR (1989) Wave transformation over coral reefs, J. Geophys. Res. 94:9779-9789. 